\title{
The Authority of Written and Oral Sources of Knowledge in Ludolf of Sudheim's De itinere Terre Sancte
}

\author{
Christine Gadrat-Ouerfelli \\ LA3M-Aix Marseille Université \\ Aix-en-Provence, France
}

10 Pilgrimage narratives that survive from the Middle Ages characteristically combine the pilgrim-writer's own personal experiences and observations while traveling, information gathered from others encountered along the way, and authoritative knowledge acquired from books, especially the Bible and biblical commentaries. As the practice of pilgrimage grew throughout the medieval period and likewise the number of pilgrimage narratives, former pilgrim-writers became reference points for later ones. Pilgrimage literature has thus often been denigrated by scholars for being repetitive, impersonal, and lacking originality. The German priest Ludolf of Sudheim, who wrote about his travels to the eastern Mediterranean islands and the Holy Land in the fourteenth century, has not been spared by such anachronistic and unproductive judgment, since it has been discovered that he, too, borrowed significantly from other pilgrimage accounts in composing his own. If scholars were to adopt a less historiographically presentist approach that is more open to the values and strategies of medieval pilgrimage narratives themselves, research could meaningfully focus on what might be called the "mental library" of pilgrim-authors the full range of written and oral resources at their disposal for building accounts of pilgrimage through complex processes for specific audiences and purposes. Analyzing Ludolf's De itinere Terre Sancte offers a good opportunity for seeing what such a perspective can bring to understanding the processes of knowledge production in pilgrimage narrative.

Ludolf of Sudheim's De itinere Terre Sancte is quite well known by 
he includes passages about Al-Andalus and the Maghrib, about India and Prester John, about Baghdad, and even about Khanbaliq. He also writes in an original way about the birds and fish of the Mediterranean. ${ }^{2}$ These elements, which are rarely found in other pilgrimage narratives, demand further investigation.

We know almost nothing about Ludolf, and what we do know comes from what he reveals in his account. ${ }^{3}$ Ludolf is "rector ecclesie parochialis," priest of Sudheim, in the diocese of Paderborn. This location explains why he dedicates his book to the bishop of Paderborn, Baldwin of Steinfurt (1341-61). ${ }^{4}$ Other than this and a few other details, Ludolf simply states that he went to Jerusalem and the Holy Land in 1336 and returned to Paderborn in 1341.5

The question of Ludolf's identity is even more uncertain when considering the different versions of his text. De itinere Terre Sancte exists in four versions, two in Latin and two in German. It also appeared early in print, in Latin in 1475-80 (published by Henri Eggestein in Strasbourg), and in German in 1476 (published by Anton Sorg in Augsburg). ${ }^{6}$ These different versions and editions, along with numerous manuscripts (about fifty) attest to the relative popularity of De itinere Terre Sancte. ${ }^{7}$ Other medieval pilgrims read it, too, including the Dominican pilgrim-writer Felix Fabri. ${ }^{8}$

We cannot be sure that the most complete Latin version edited by Ferdinand Deycks was the original work. Two German translations were made, but the exact chronology and relationship between them is not known. An additional Latin version, which is preserved only in a fifteeenthcentury compilation, was made by a Cistercian monk from Oldenburg, Detmar de Hude, who may have rewritten and omitted some parts of the text. ${ }^{9}$ However, this version features personal information about Ludolf and may represent another (perhaps the first) draft made by Ludolf himself. For example, the "Detmar" text relates that Ludolf went to the Orient to accompany a knight in the service of the king of Armenia; that his name was Ludolfus Clippeator ("Ludolf Schilder" in German); and that he was priest in the diocese of Osnabrück, who dedicated his book to Gottfried, the bishop of Osnabrück (Gottfried of Arnsberg, 1321-49). ${ }^{10}$ These details are surprisingly consistent with those in Deckys's edition, and they may very well be true; they suggest that Ludolf was the author of this version as well.11

The lack of a modern critical edition of De itinere Terre Sancte poses a challenge for scholars. The main Latin version was published by Ferdinand Deycks in 1851, and it was followed by Guillaume Antoine Neumann's edition of the other Latin version published in Archives de l'Orient Latin in 
1884. ${ }^{12}$ The Old High German version was edited in 1861 by Johann Gottfried Kosegarten, and the Low German appeared much later, issued in 1937 by Ivar von Stapelmohr. ${ }^{13}$ All these editions were based on a small number of manuscripts, and their apparatuses are rather poor. Ferdinand Deycks, whose edition I use here, provides only the spelling variations found in two Latin manuscripts and in one Latin and two German printed editions. He attempts to identify names and places, but there are many errors and omissions. ${ }^{14}$ For example, at the beginning of the text, Ludolf states that Europe and Africa are separated by a river, which is called Inda, and that this river flows through the city of Biterris, which was built at the time Hannibal crossed Spain and the south of France to go to Italy. ${ }^{15}$ Deycks comments that this must be the Indre River in Berry (in central France), but Hannibal never traveled that far north. ${ }^{16}$ Deycks indicates that in another manuscript the spelling is "Anda," which might have suggested that this river mentioned by Ludolf is most likely the Aude_-substituting " $n$ " for " $u$ " being a very common scribal error. The Aude flows in the south of France, from the Pyrenées to the Mediterranean near Narbonne, not far from "Biterris." This is the actual city of Beziers, which Deycks does not identify at all.

Another example of such insufficiency in Deycks's edition is apparent when Ludolf writes about William of Boldensele, another German pilgrim who went to the Holy Land a few years before him. Ludolf relates that in Hebron he met three men who were the former "familiares" of "dominus Wilhelmus de Bolensele."17 Deycks, apparently totally ignorant of who William of Boldensele was, supposes that "Es muss ein westfälischer Ritter sein" [He must be a knight from Westphalia], but is unaware of William as a pilgrim and author of his own pilgrimage narrative. Certainly, Boldensele's pilgrimage account was not readily accessible at the time Deycks published his edition of Ludolf, but examples like this show that this edition of De itinere Terre Sancte is simply not reliable. ${ }^{18}$ Moreover, Deycks does not identify the sources used by Ludolf, a critical omission that is unfortunately common in the other editions of Ludolf's narrative.

The lack of biographical information about Ludolf leaves his social status uncertain. Although it is supposed that he traveled as a chaplain of a knight, which knight is unknown. Nothing is known of his education, whether he attended university, or how else he might have had access to the knowledge displayed in his work. The level of detail found in De itinere Terre Sancte indicates he was able to gather a respectable amount of information about places, whether he visited them or not. At the same time, his knowledge is imperfectly assimilated, or too quickly read, as much is 
confused. This prompts further questions: How was it possible for Ludolf to acquire this knowledge? Had he collected a personal library? Did he use the library of the knight with whom he traveled, or, rather, a monastic or episcopal library upon his return to Germany? For the moment, we can only pose but not fully answer these questions.

In the prologue to De itinere Terre Sancte, Ludolf acknowledges that he borrowed from others to write his book- "I excerpted some things from antique histories" - but he does not cite the names of any authors or titles. ${ }^{19}$ He does not conceal the fact that he did not write solely from his own experience. In his introduction, Ludolf indicates three types of sources upon which he drew: his own observations, his reading, and what he heard from "faithful men." 20 The association of personal experience with things heard while traveling is a commonplace in pilgrimage narratives and in travel accounts more broadly. ${ }^{21}$ Odorico da Pordenone, a slightly older contemporary of Ludolf, makes much use of formulas of seeing and hearing such as "vidi" and "audivi.". ${ }^{2}$ Ludolf's admission of incorporating what he read into his account is a less common feature, but more striking is the way he combines several types of sources at particular points in his narrative.

On occasion, Ludolf indicates his sources of information more precisely. However, these instances remain rather puzzling, and the reader wonders if the author can be believed completely, or if his remarks require interpretation. That is the case, for example, when he tells us about Baghdad and how the Mongols seized the city. He begins by explaining how he obtained information about that historical event: "About the loss of the city of Baghdad I would say little, following what I read in annals and histories of the kings of Armenia, and what I heard from a very faithful soldier, who was there." 23 These annals of the kings of Armenia are, in fact, Hayton or Hethum's Flos historiarum Terre Orientis, a history of the Eastern world, especially about the Muslim conquests and Mongol invasion, written in French by an Armenian prince (and Premonstratensian monk) in 1307, which was then immediately translated into Latin. This text appears to be the unique source of Ludolf's passage, as he follows it faithfully, keeping the same order of the events and only slightly abridging them. ${ }^{24}$ However, Ludolf also adds the testimony of an eyewitness: a soldier who had participated in the battle. The identity of this soldier is not known, but he is certainly not the source of the account as it appears in the book. Baghdad was seized in 1258, that is, about eighty years before Ludolf embarked on his pilgrimage; he could not have met someone who had been present at the battle. Either Ludolf or the man whom he met is lying. In any case, Ludolf 
did not insert this testimony in his account without reason. Mentioning this source certainly is meant to add authority to his own words and affirm more insistently the story's truth. In Ludolf's mind, an oral source from an eyewitness is superior to a written one. He values what he can obtain from conversation above what he can learn in books.

Indeed, in many passages of De itinere Terre Sancte, Ludolf mentions oral sources of knowledge or his attempts to find someone able to give him information. That is the case at the beginning of his chapter on Baghdad, when he speaks of Antique Babylonia, saying he will not say anything further because he could not find anyone to teach him: "I cannot tell something else true [aliud veri] about Antique Babylonia, and I could never get anything else about it in these countries from any people." 25 The "aliud veri" expression is noteworthy: he tried to get reliable information from oral sources, from actual people with whom he could meet and talk. Ludolf in effect praises knowledge gathered from conversation over that found in books.

Ludolf mentions oral sources in many other places in his text. These include the marvels that he relates about fish of the Mediterranean, such as an account of a giant fish that bit into a boat, leaving its tooth in a plank. Ludolf makes a point of stating that he gathered such stories from experienced sailors: "I heard from a very famous sailor telling me . . . "; "I also heard from a very faithful sailor, who knew every maritime itinerary and had experienced many horrible dangers in the sea. ".26 Even if these stories might seem like tales told by sailors to credulous travelers to impress them or to pass the long hours on board a ship, Ludolf stresses the experience and reliability of these sailors.

Ludolf's empoyment of terms from different vernacular languages also indicates the extent to which he resorts to oral sources. In one instance, for example, when referring to a fish, he gives the name of "melar," that is, "according to the "Galici." 27 The fact that his referencing of vernacular words throughout the text come from different languages is a sign that Ludolf actually spoke to local people in various stops along his travels. Ludolf references words from French, as in the name of the place called "gulph de leun"; words from Greek, as in the name "Ayos Yamos," a city built close to ancient Troy; and words from Italian, as in "pomica," the name Sicilians gave to stones ejected by Mount Etna. ${ }^{28}$ Even words from Arabic are mentioned: for example, the "regnum de Garp" for the Algarve; or the different names of Shawbak fortress, "in arabico Arab, in chaldaico Schobach, in latino Mons regalis," all of which are accurate. ${ }^{29}$ 
Table 1. Comparison of passages on the Mediterranean Sea in William of Boldensele and Ludolf of Sudheim.

\section{William of Boldensele}

Dicitur hoc mare Mediterraneum quia principalibus mundi partibus, scilicet Asie, Affrice et Europe interjacet, ipsas se et suis brachiis ab invicem separans et distinguens. Habet enim ab occidente et septentrione Europam, ad orientem Asiam, ad austrum Affricam, et uno brachio ejus quo attingit Hispaniam, et strictum de Maroch vulgariter dicitur, continuatur hoc mare Mediterraneum cum occeano, mari scilicet maximo quod orbem circumfluit. Altero vero ejus brachio, quod Elespontus seu brachium Sancti Georgii dicitur, continuatur cum mari Pontico quod quasi nullam habet insulam, unde et mare Majus nuncupatur.

\section{Ludolf of Sudheim}

\begin{abstract}
Et est notandum quod inter Marrochiam et Hispaniam mare Mediterraneaum influit ex oceano per brachium latitudinis vix quartae partis unius miliaris. Itaque in una ripa stat mulier christiana et in alia ripa stat mulier barbara vestimenta eorum lavantes et ad invicem rixantes et contendentes, et dicitur illud brachium maris ab incolis Strit de Balthar et alio nomine Strit de Marroch. Et isto parvo brachio maris transito potest iri per terram per totum mundum versus meridiem, ut dixi, si non sunt obstacula. Et per istud brachium reges Marrochiae et Granati regi de Garp veniunt in auxilium; nam leniter hoc transeunt. Et sicut mare Mediterraneum per hoc brachium inter Marroch et Hispaniam ex oceano influit, sic eodem modo mare Mediterraneum in mare Ponticum effluit prope muros Constantinopolis per brachium maris, quod ab incolis brachium sancti Georgii vocatur, eiusdem latitudinis ut prius.
\end{abstract}

When considering Ludolf's written sources, it is well known that he borrowed information from William of Boldensele's pilgrimage account, Liber de quibusdam ultramarinis partibus, although no one has yet traced his borrowings with precision. ${ }^{30}$ Boldensele went to the Holy Land between 1331 and 1335, and he wrote his report of his pilgrimage in 1336, the year that Ludolf states he himself arrived in the Holy Land. ${ }^{31}$ Yet, it does not appear that Ludolf borrowed verbatim from Boldensele. Many comparable passages in De itinere Terre Sancte and Liber de quibusdam ultramarinis partibus provide similar information, but not the same wording or even exactly the same historical facts or anecdotes. For example, at the beginning of both texts, there is a brief, schematic description of the Mediterranean and its two mouths, the Straits of Gibraltar and Saint George (see table 1).32 Both texts are somewhat similar, but Ludolf adds information that is not provided by Boldensele, such as the distance between Spain and Morocco (a quarter of a mile), a vernacular name of the Strait of Gibraltar ("Strit de Balthar"), and an anecdote about how on both sides of the strait two washerwomen, a pagan in Morocco and a Christian in Spain, insult each other across the span. Ludolf did not leave any trace of this anecdote's source, yet this exam- 

differences in verb forms used.

De Castro igitur quod Darum dicitur processi versus Egiptum per desertum arenorum in VII diebus. In quo deserto est aque penuria, portavique victualia et alia necessaria in camelis. Sunt tamen ordinata per Sarracenos certa secundum dietas hospitia ubi inveniuntur necessaria competenter.

Post veni in Egiptum ubi sunt casalia pulcherrima infinita, omnibus bonis temporalibus habundantia, preterquam quod in terris Sarracenorum per Sarracenos vinee non coluntur nec porcos nutriunt, hoc eis lege ipsorum que in libro quem Alkoranum dicunt scribitur strictius inhibente. Et primo procedens versus Babyloniam veni ad villam famosam et XXIX. De Aegypto
De castro Dar, proceditur in Aegyptum per desertum arenosum in septem diebus. In hoc deserto quasi nullorum necessariorum est penuria, excepta aqua, quae tamen in utris et camelis bene deportatur. Per singulas diaetas inveniuntur bona Sarracenorum hospitia et, excepto vino, omnia necessaria.

magnam, que Belbeis nominatur.

Hoc deserto transito pervenitur in Aegyptum, in cuius introitu sunt plurima pulcherrima et delectabilia loca omnibus bonis rebus, quas humanum cor excogitare potest, et omnibus necessariis, excepto solo vino, plena. Et sic procedendo versus Babyloniam novam, pervenitur ad pulcherrimam villam et delectabilem, nomine Belyab.

ple shows that Ludolf did not copy this passage directly from Boldensele, or that, while may have drawn upon his contemporary's work, he made it his own by rewriting and completing it.

Other parts of Ludolf's text are more obviously taken from Boldensele: for example, when Ludolf describes his leaving Palestine for Egypt, he quite literally repeats Boldensele's words, even using the same measures of time and space. The main change in this passage, outside omitting the reference to the Koran, is that Ludolf uses impersonal verb forms ("proceditur," "pervenitur," etc.), while Boldensele writes in the first person (see table 2). 33 The transformation of the personal point of view into an impersonal one could be interpreted as a sign of borrowing, but a close reading of Ludolf's text does not confirm this. The impersonal form is, in fact, rather characteristic of Ludolf's writing in general, and he uses it extensively throughout his book, even in passages where he probably does not borrow from anyone else. This gives his book the appearance of a pilgrimage guide rather than a personal account. ${ }^{34}$ Ludolf sometimes uses the first-person viewpoint, too, but much less frequently, and always to affirm that he himself was present at a given location and saw what he writes about, or that he personally heard details from informants whom he describes to his readers. For example, his 
description of Cairo and Babylonia (that is, Fustat) is very close to that of Boldensele; but when Ludolf adds a piece of information lacking in Boldensele, he gives his source and uses the first person: "I have heard from merchants that Cairo is estimated to be seven times bigger than Paris." 35 Doing so is a way of emphasizing the origin of his information and to guarantee its accuracy with the authenticity implicit in the use of the first-person point of view. ${ }^{36}$ This characteristic can be seen in the passage already discussed concerning Baghdad, where Ludolf tells us that he heard the story of the Mongols' seizure of the city from a soldier who claimed to have been present. What is strange about Ludolf's use of Boldensele is that, although he borrows much from him, Ludolf does not leave the reader with a good impression of Boldensele. When an author writing in the genre of the pilgrimage narrative borrows from another writer, he usually praises his source as a way to add value to his own work. However, Ludolf does exactly the contrary. When he mentions Boldensele, he relates that this pilgrim betrayed his three companions, abandoning them in Hebron, where they led a miserable existence. ${ }^{37}$ The version of this account by Detmar de Hude provides additional details about Boldensele, revealing that he had absconded from the Dominican convent of Minden, of which he was a member. ${ }^{38}$ Ludolf's main source, therefore, does not seem to have enjoyed a good reputation, nor does Ludolph attempt to remedy it.

It is clear that Ludolf had not only heard about Boldensele's book, but he had read it himself, because Ludolph's borrowed material follows its source closely. The Liber de quibusdam ultramarinis partibus possessed a respectable medieval readership and is still preserved in twenty-three manuscripts. ${ }^{39}$ Many of these are of Germanic origin, so it is likely that Boldensele's text would have been readily available to Ludolf upon his return home. ${ }^{40}$ At the same time, Ludolph had access to oral information about the text's author, enabling him to offer information about Boldensale's life that Boldensele himself does not provide in his book. Moreover, Ludolf was also aware of Boldensele's death: "as I heard, he ended his life in Colonia." 41 Boldensele made the Holy Land pilgrimage only a few years before Ludolf; we may well wonder if they had a shared acquaintance.

We know that Ludolf read other pilgrimage accounts to enlarge his own narrative. He read William of Boldensele's pilgrimage account and Hethum's Flos historiarum Terre Orientis. He also cites the Bible several times. A complete and careful study of De itinere Sancte Terre will certainly reveal other written sources. Yet more than those written sources, Ludolf seems to value oral information from eyewitnesses the most. All along his 
travels, he spoke with the people he met, among them the sailors on board vessels taking him to different ports of the Mediterranean and then to the Holy Land, the merchants he found in Egypt, and the Christian apostates and former companions of William of Boldensele who lived in Hebron. Ludolf's narrative reveals its author to be a very curious man, eager to learn new things, ready to ask questions of those he met. This gregarious inquisitiveness allowed Ludolph to acquire stores of knowledge beyond the bounds of written sources, enriching both his mental library and the written account of his travels. ${ }^{42}$

\section{Notes}

I thank Kathryn Beebe, Michael Cornett, and the anonymous reader for JMEMS for their suggestions and helpful editing, which have improved the final version of my article.

1 The literature about Ludolf of Sudheim is far from abundant. See Georg Schnath, "Drei niedersächsische Sinaipilger im 1330: Herzog Heinrich von BraunschweigGrubenhagen, Wilhelm von Boldensele, Ludolf von Sudheim," in Festschrift Percy Ernst Schramm zu seinem siebzigsten Geburtstag von Schülern und Freunden zugeeignet, ed. Peter Classen and Peter Scheibert, vol. 1 (Wiesbaden: F. Steiner, 1964), 461-78; Bernhard Jahn, Raumkonzepte in der frühen Neuzeit: Zur Konstruktion von Wirklichkeit in Pilgerberichten, Amerikareisebeschreibungen und Prosaerzählungen (Frankfurt am Main: Peter Lang, 1993), 22-143; Christian Halm, Europäische Reiseberichte des späten Mittelalters: Eine analytische Bibliographie, vol. 1, Deutsche Reiseberichte (Frankfurt am Main: Peter Lang, 1994), 36\$44; Jacob Klingner, "Ludolf von Sudheim," in Deutches Literatur Lexikon: Das Mittelalters, vol. 3, Reiseberichte und Geschichtsdichtung, ed. Wolgang Achnitz (Berlin: De Gruyter, 2012), 383-87; C. Gadrat-Ouerfelli, "Identité(s) d'un voyageur médiéval: Ludolf de Sudheim," in Le voyage au Moyen Âge: Description du monde et quête individuelle, ed. Damien Coulon and Christine Gadrat-Ouerfelli (Aix-en-Provence, Fr.: Presses universitaires de Provence, 2017), 95-104; Susanna E. Fischer, Erzählte Bewegung: Narrationsstrategien und Funktionsweisen lateinischer Pilgertexte (4.-15. Jahrhundert) (Leiden: Brill, 2019), 264-99.

2 On Ludolf's discussion of birds and fish of the Mediterranean, see C. GadratOuerfelli, "Le regard de deux pèlerins allemands sur la Méditerranée et ses marins," in La vida maritima a la Mediterrània medieval: Fonts històriques i literàries, ed. Lola Badia, Lluis Cifuentes, and Roser Salicru i Lluch (Barcelona: Museu Marítim de Barcelona, Publicacions de l'Abadia de Montserrat, 2019), 149-63, at 156-58.

3 Gadrat-Ouerfelli, "Identité(s) d'un voyageur médiéval: Ludolf de Sudheim"; Schnath, "Drei niedersächsische Sinaipilger im 1330: Herzog Heinrich von Braunschweig-Grubenhagen, Wilhelm von Boldensele, Ludolf von Sudheim," 461-78.

4 Ludolphi, rectoris ecclesiae parochialis in Suchem, De itinere Terrae Sanctae liber, ed. 
Ferdinand Deycks (Stuttgart, 1851), 1: "Reverendissimo in Christo patri ac domino, domino suo gratioso Baldewino de Stenvordia, Paderbornensis ecclesiae episcopo, Ludolphus rector ecclesie parochialis in Suchem, paderbornensis dioecesis, debitam reverentiam et honorem." References are to Ludolf, De itinere Terre Sancte. Translations are my own unless otherwise indicated.

5 Ludolf, De itinere Terre Sancte, 2: "ipsas partes ultramarinas et earum statum anno domini MCCCXXVI inveni, et ipsas partes et earum statum anno domini MCCCXLI reliqui."

6 On Henri Eggestein's edition of De Terra sancta et itinere Iherosolomitano et de statu eius et aliis mirabilibus, que in mari conspiciuntur, videlicet mediterraneo, see Incunabula Short Title Catalogue: The International Database of 15th-Century European Printing, ISTC (London: British Library, Consortium of European Research Libraries, 2016- ), il00362000; and Gesamtkatalog der Wiegendrucke (Leipzig: K. W. Hiersemann; Stuttgart: Anton Hiersemann, 1925- ), M 44167. On Anton Sorg's edition of Hie hebet an das buch von dem weg oder zu dem heylige grab oder gelobten land und wundern da bey vast kurtzweilig begriffen, see Incunabula Short Title Catalogue, il00364900; Gesamtkatalog der Wiegendrucke, M 44173.

7 The exact number of manuscripts is not certain; various lists give different numbers and different manuscript shelfmarks. The more complete and accurate ones can be found at Archives de littérature du Moyen Âge (ARLIMA), ed. Laurent Brun, University of Ottawa, Sept. 2005, www.arlima.net; and European Travel Accounts of the Late Middle Ages (2018 relaunch of Digitized Travel Accounts of Late Medieval and Early Modern Europe, Academy of Sciences and Humanities at Göttingen, 2006), at www .digiberichte.de, which reproduces the list from Halm, Europäische Reiseberichte des späten Mittelalters, vol. 1, Deutsche Reiseberichte, 36-44. I am currently checking these lists and working to establish a precise manuscript bibliography.

8 Felix Fabri, Les errances de frère Félix, pèlerin en Terre sainte, en Arabie et en Égypte, ed. Jean Meyers and Michel Tarayre, vol. 1 (Paris: Classiques Garnier, 2013), 44.

9 Guillaume Antoine Neumann, "Ludolphus de Sudheim: De itinere Terre sancte," Archives de l'Orient latin 2 (1884): 305-77.

10 Ludolfs von Sudheim Reise ins Heilige Land, nach der Hamburger Handschrift herausgegeben, ed. Ivar von Stapelmohr (Lund: C. W. K. Gleerup, 1937), 12: "quidam clericus Osnabrugensis nomine Ludolfus Clippeator, qui noviter de sancta terra venerat et ibi quinque annis cum domino, qui fuit miles regis Armenie, permanserat in peregrinatione et omnia ista oculis vidit et quedam parva a fide dignis audivit, quedam autem in historiis regum legit et ad preces venerabilis in Christo patris Gotfridi, quondam Osnabrugensis episcopi, nunc autem Bremensis in sancte patris redegit."

11 See the remarks made by Schnath, “Drei niedersächsische Sinaipilger im 1330," 469.

12 Neumann, "Ludolphus de Sudheim: De itinere Terre sancte."

13 Ludolfvon Suchens Reisebuch ins Heilige Land, ed. Johann Gottfried Kosegarten (Greifswald, 1861); Ludolfs von Sudheim Reise ins Heilige Land, ed. von Stapelmohr.

14 See Deycks, ed., De itinere Terre Sancte, xxii-xxiv.

15 Ludolf, De itinere Terre Sancte, 8-9: "Affrica et Europa, ut audivi, distinguuntur cum quodam flumine nomine Inda, in quo XL martyres fuerunt submersi, et idem flumen 
16 Deycks, ed., De itinere Terre Sancte, 8-9: "Doch wohl der Fluss Indre in Berry. Denn dorthin deutet die ganze wunderliche Erzählung. Wer Hanibaldus sei, entscheide ich nicht. In M. heisst er Hannibal, doch sonst nirgends. Der Name des Flusses Inda steht nur in A. B hat Anda."

17 Ludolf, 71: "Temporibus meis fuerunt in Hebron tres renegati de dioecesi mindensi. . . . Hi tres fuerunt familiares cuiusdam militis de partibus istis, nomine dominus Wilhelmus de Bolensele, qui ante tempus meum stetit in partibus ultramarinis."

18 The first critical edition of this text is indeed very recent: Guillaume de Boldensele, Sur la Terre sainte et l'Égypte (1336): Liber de quibusdam ultramarinis partibus, ed. Christiane Deluz (Paris: CNRS éditions, 2018). Boldensele's Latin pilgrimage account is accompanied here by its translation into French by Jean de Long in 1351. Further citations of Boldensele's text are to Liber de quibusdam ultramarinis partibus.

19 Ludolf, De itinere Terre Sancte, 2.

20 Ludolf, 2: "Verumtamen nullus credat, me omnia et singula, quae inserere propono, oculis vidisse, sed ex antiquis gestis bene aliqua extraxisse, et aliqua ex veridicis hominibus audisse, quae omnia, in quibus locis scribantur et inveniantur, discreti lectoris iudicio duxi committendum."

21 This association can already be found in some of the oldest pilgrimage accounts: see Thomas O’Loughlin, "Adomnán and Arculf: The Case of an Expert Witness," Journal of Medieval Latin 7 (1997): 127-46. See Michèle Guéret-Laferté, Sur les routes de l'empire mongol: Ordre et rhétorique des relations de voyage aux XIIIe et XIVe siècles (Paris: Honoré Champion, 1997), 171-78; Marina Münkler, Erfahrung des Fremden: Beschreibung Ostasiens in den Augenzeugenberichten des 13. und 14. Jahrhunderts (Berlin: Akademie Verlag, 2000), 282-84; Fischer, Erzählte Bewegung, 38-40.

22 See, for example, a comment from the introduction to Odorico da Pordenone, Relatio de mirabilibus orientalium Tatarorum, ed. Annalia Marchisio (Firenze: SISMEL, Edizioni del Galluzzo, 2016), 119: "multa magna et mirabilia audivi atque vidi que possum veraciter enarrare" [Many great and mirculous things I have heard about or even seen that I am able to relate truly]. "Vidi" and "audivi" appear frequently throughout the text.

23 Ludolf, De itinere Terre Sancte, 56: "De cuius civitatis Baldach perditione modicum dicam, prout in annalibus et historiis regum Armeniae legi, et a valde veridico milite, qui interfuit, audivi."

24 Ludolf slightly abridges chapters 13 and 14 of Hethum's book 2. See Die Geschichte der Mongolen des Hethum von Korykos (1307) in der Rückübersetzung durch Jean le Long: Traitiez des estas et des conditions de quatorze royaumes de Aise (1351), ed. Sven Dörper (Frankfurt am Main: Peter Lang, 1998), 262-73.

25 Ludolf, De itinere Terre Sancte, 56: "Nil aliud veri possum dicere de Babylonia antiqua, nec umquam in partibus illis ab aliquibus hominibus potui investigare."

26 Ludolf, 12 and 13: "Audivi a valde notabili nauta mihi dicente ..."; "item audivi ab alio valde veridico nauta, qui quasi omnia maris novit itinera et quam plurima et varia horribilia in mari passus fuit pericula...."

27 Ludolf, 13: "piscem quem Galici melar appellant." 
28 Ludolf, 18: "gulph de leun, id est ira leonis"; 17 (for Hagios Ioannis); and 19.

29 Ludolf, 6 and 89. "Arab" refers to Wadi Arab, in the Jordan Valley, where Shawbak fortress stands; "Mons regalis" is the Latin for Montreal.

30 Boldensele, Liber de quibusdam ultramarinis partibus, 34.

31 See Boldensele, 19.

32 The respective passages are from Boldensele, Liber de quibusdam ultramarinis partibus, 68; and Ludolf, De itinere Terre Sancte, 7-8. For a discussion of these passages in both texts, see Christine Gadrat-Ouerfelli, "Le voyage," in La terre: Connaissance, représentations, mesure au Moyen Âge, ed. Patrick Gautier Dalché (Turnhout, Belg.: Brepols, 2013), 505-79, at 559-65.

33 The respective passages are from Boldensele, Liber de quibusdam ultramarinis partibus, 80; and Ludolf, De itinere Terre Sancte, 51.

34 See Fischer's similar observation in Erzählte Bewegung, 283-84.

36 See Guéret-Laferté, Sur les routes de l'empire mongol, 169-80.

37 Ludolf, De itinere Terre Sancte, 71: "Temporibus meis fuerunt in Hebron tres renegati de dioecesi Mindensi. . . Interrogati, cur se renegassent, dixerunt, quod sperassent ut dominus eorum consequi debebat divitias et honores, quod eos fefellit. ... Hi tres fuerunt familiares cuiusdam militis de partibus istis, nomine dominus Wilhelmus de Bolensele, qui ante tempus meum stetit in partibus ultramarinis, et ibidem a Soldano et regibus et aliis principibus fuit mirifice honoratus, et, ut audivi, in Colonia diem clausit extremum."

38 Neumann, "Ludolphus de Sudheim: De itinere Terre sancte," 346-47: "In Ebron visi eciam sunt renegati de diocesi Myndenensi, aquam in utribus venalem portantes, miseri et male vestiti, olim famuli Wilhelmi de Voldensele, apostate de ordine Praedicatorum, domus in Mynda, qui se pro milite habuit et litteras regis Grecorum hinc inde deportavit et magnum honorem apud Soldanum aliosque principes et divitias adeptus fuit; qui ante tres annos in Colonia obiit, ubi non apud Fratres, sed in alia ecclesia ut miles sepultus fuit."

39 Boldensele, Liber de quibusdam ultramarinis partibus, 37-47.

40 Hethum's Flos historiarum is also preserved in several manuscripts from Germanic origin (Die Geschichte der Mongolen des Hethum von Korykos, 57-73).

41 Ludolf, De itinere Terre Sancte, 71.

42 On the "mental libraries" of pilgrims, see Nicole Chareyron, Éthique et esthétique du récit de voyage à la fin du Moyen Âge (Paris: Honoré Champion, 2013), 386-405. 